\title{
Research on the Construction of Curriculum System of Innovation and Entrepreneurship Education in Tourism Management
}

\author{
Fu Maozheng \\ Hainan Institute of Science and Technology
}

279133771@qq.com

\begin{abstract}
Keywords: Tourism management; innovation and entrepreneurship education; curriculum system
\end{abstract}
\begin{abstract}
In recent years, the world tourism economy has been growing, and there are more and more entrepreneurial opportunities in the tourism industry. The demand for innovative and entrepreneurial talents is also increasing. However, at present, there are still many problems in the innovation and entrepreneurship education of tourism management in China, which leads to the low quality of tourism innovation and entrepreneurship. This obviously does not meet the current social development situation. This paper explores the significance of innovation and entrepreneurship education in tourism management, analyzes the problems existing in the process of development, and then proposes to build a curriculum of innovation and entrepreneurship education, and builds on the curriculum system, strengthens the construction of teaching staff, builds a practical platform and creates a strong innovation and entrepreneurship. The atmosphere, organic integration of innovation and entrepreneurship education and tourism management, and effectively improve the quality of personnel training.
\end{abstract}

\section{Introduction}

In 1989 , UNESCO first proposed the concept of "entrepreneurial education" and advocated the cultivation of entrepreneurial spirit and entrepreneurial skills. In the 21 st century, innovation and entrepreneurship education has become an important concept for talent cultivation in countries around the world. In the process of economic development, especially reform and innovation, entrepreneurship education has made important contributions. China's entrepreneurship education started in 2002, which started late compared with developed countries, and seriously lags behind the requirements of China's economic and social development reform and innovation. Until recently, the state and the government have discovered that to promote social and economic development, we must attach great importance to entrepreneurship education. Therefore, the state and the government provide strong support for entrepreneurship education, open entrepreneurship courses for university students, provide financial support, and improve consulting services. While cultivating college students' professional knowledge, they will carry out practical activities, cultivate their innovative ability, innovation consciousness and entrepreneurial spirit, so that more and more university graduates can start their own businesses. This is also the core goal of entrepreneurship education. In this regard, based on the research of innovation and entrepreneurship education in colleges and universities, this paper analyzes the significance of innovation and entrepreneurship education, puts forward the implementation path of the curriculum of innovation and entrepreneurship education in tourism management, expands the platform of innovation and entrepreneurship education, and cultivates students' ability of innovation and entrepreneurship.

\section{Importance of reform of the innovation and entrepreneurship curriculum system for tourism management}

To meet the needs of the tourism market, human resources

At present, China's society needs a large number of entrepreneurial, high-quality, composite tourism management talents. With the rapid development of China's tourism industry, the demand for tourism management talents has gradually increased. This also provides more convenient conditions 
for tourism and entrepreneurship. Among them, the entry barriers for small and medium-sized enterprises such as budget hotels, small and medium-sized travel agencies, rural tourism, and catering enterprises have reduced the difficulty of innovation and entrepreneurship to a certain extent. SMEs meet the needs of market development and have a large space for development. Therefore, reforming the tourism management profession's innovation and entrepreneurship curriculum will enhance the innovation and entrepreneurial ability of the students, and can meet the needs of the tourism human resources market.

Improve students' employability

With the continuous expansion of colleges and universities in China, the number of college students has increased sharply, the employment situation has become increasingly severe, and the employment pressure faced by graduates has become more and more serious. "Difficulties in employment" has become a common concern of all sectors of society in China. In this era of situation, the employment pressure of tourism management students is also increasing. The research shows that if the proportion of college students' innovation and entrepreneurship can reach $10 \%$, it can alleviate the current employment pressure to a certain extent. Innovating the tourism management professional innovation and entrepreneurship curriculum system can effectively enhance the students' awareness of innovation and entrepreneurship, and encourage them to start their own businesses, thereby enhancing their employment competitiveness and social adaptability.

To promote training in universities objectives into

Innovative entrepreneurship education is in line with the educational philosophy of "people-oriented, promoting the all-round development of college students". College tourism management majors should not only guide students to master rich professional knowledge and skills, but also pay attention to students' ability of innovation and entrepreneurship, which is also the inherent requirement of current social development. At present, the training objectives of many college tourism management majors are relatively narrow, and they still fail to break the framework of "postgraduate entrance examination and basic employment", which is obviously not conducive to the overall development of college students. Therefore, innovating the tourism management professional innovation and entrepreneurship curriculum system, can promote the timely transformation of teaching objectives, and start to cultivate innovative, composite and applied tourism management professionals.

\section{The status quo of tourism management professional innovation and entrepreneurship education}

The concept is relatively backward, lack of thinking

The concept is relatively backward, and the lack of ideological understanding is a common problem in the innovation and entrepreneurship education of colleges and universities. The tourism management profession is similar. Most managers also limit innovation and entrepreneurship education to engage in activities and participate in competitions. They believe that innovation and entrepreneurship education is a niche education model for a small number of students with entrepreneurial aspirations and potential, and belongs to the "elite" education, so they are worried. Wait and see attitude. At the same time, many students also believe that innovation and entrepreneurship education is mainly carried out for students who are engaged in entrepreneurship. In terms of concept, innovation and entrepreneurship education is not regarded as part of general education and quality education, and student participation is low. Colleges and universities lack capital investment in curriculum construction and training of teachers. The software and hardware environment are not satisfactory. The atmosphere of innovation and entrepreneurship education is not strong, and innovation and entrepreneurship education is difficult to carry out effectively.

Innovation and entrepreneurship education curriculum incomplete

The innovation and entrepreneurship education in China's colleges and universities is in its infancy, and its curriculum system is not complete enough. For example, the overall orientation of the curriculum is not clear, and the whole process of talent cultivation is not carried out. The content of the curriculum is lightly theoretical and can not be effectively connected with social 
needs. In the teaching team, the lack of a professional and stable faculty, the research on the curriculum is not deep enough, it is difficult to guarantee the actual effect of the course. Most of the innovation and entrepreneurship education in colleges and universities rely on career planning and employment guidance courses. There are few innovative entrepreneurship courses presented in the form of individual courses. Students' awareness of innovation and entrepreneurship is weak, and innovation and entrepreneurship education and ability training are impossible to talk about. Most tourism management professionals rely only on teachers with professional backgrounds in tourism management to sporadically mention innovation and entrepreneurship education in employment courses, which is far from meeting the requirements of professional talent training.

\section{The principles of innovative entrepreneurship education curriculum design}

Highlight the principle of application. The tourism management profession regards students' professional skills application ability as an important training goal. In the innovation and entrepreneurship education, the curriculum content setting should fully train students' professional skills application ability, improve students' comprehensive quality, and enable students to truly understand through innovative and entrepreneurial education. The characteristics and advantages of the tourism management profession.

Focus on the principle of characteristics. Many local undergraduate colleges generally offer courses related to innovation and entrepreneurship education, and there are many successful models. However, the curriculum of innovation and entrepreneurship education in the tourism management profession should be combined with the actual situation of the profession and the regional conditions, and some special and effective courses should be set up to avoid similarization. It is not possible to simply copy and imitate the practices of other schools and other professions.

The principle of combining with professional courses. At present, many local colleges and universities offer different professional courses and innovative entrepreneurship courses, but there are not many combinations of the two. Many of the majors in the innovation and entrepreneurship education curriculum are general education courses. The professional courses and entrepreneurial practice courses are highly differentiated, and they do not really improve the comprehensive quality of students' innovation. The tourism management professional innovation and entrepreneurship curriculum should be systematically and closely combined with the professional courses of the major to make the students' innovation and entrepreneurial activities more targeted.

The principle of reflecting the needs of the times. Tourism has a strong era, the market changes with each passing day, and the frequency of industrial upgrading is faster. This requires that the curriculum of innovation and entrepreneurship education in tourism management should keep up with the trend of the times, keep pace with the times, and improve the success rate of innovation and entrepreneurial activities.

The principle of continuity. According to the relevant surveys, most local undergraduate colleges have opened courses on innovation and entrepreneurship education in the professional talent training program, but less than $20 \%$ from the first grade to the fourth grade. In order to strengthen the continuous influence and promotion of innovation and entrepreneurship education on students, the tourism management profession should maintain the continuity of the curriculum in the course of setting up innovative entrepreneurship education, while ensuring the continuity of teaching time.

\section{The main way for tourism management major to carry out innovation and entrepreneurship education}

Changing ideas, play an exemplary role of teachers

Tourism management professional teachers are the first in the industry that students are exposed to. They are role models for students to learn. Teachers' innovative consciousness, innovative spirit, entrepreneurial literacy, and entrepreneurial ability will have a subtle influence on students. Tourism management professional teachers should fully recognize the importance and urgency of carrying out the innovation and entrepreneurship education curriculum system, to create a sense of 
innovation and entrepreneurship, to teach college students the innovation and entrepreneurship knowledge, to cultivate college students' innovative and entrepreneurial ability, and to have a passion for their own work. We have a sincere love for our students. Everything shows the teacher's concept of innovation and entrepreneurship. With strong sense of innovation, positive innovation, good entrepreneurial literacy and superb entrepreneurial ability, we have become a model for students to learn and be good teachers and friends.

Make full use of classroom teaching, expand the platform of innovation and entrepreneurship education

In the first classroom teaching, first of all, through the Internet platform to obtain more tourism management research hot spots and research frontiers, in the classroom teaching, combined with the course content, transfer to students, arouse students' thinking, improve students' creative thinking ability. Secondly, in the classroom teaching, can directly link to each other. On the Internet, as an example of explaining theoretical knowledge, it is vivid, lively, instant and effective. Third utilize the excellent micro class resources on the Internet to carry out the teaching of related contents. In the second classroom teaching, we recommend some excellent network curriculum resources to students, such as excellent tourism planning and design company website, tourism planning and planning cases, and so on, and put forward corresponding requirements and problems, so that students will take problems after class to understand the relevant problems and cultivate creative thinking and ability. Guide students to participate in entrepreneurship competition, collect relevant information from the Internet, and cultivate innovative and entrepreneurial awareness.

Highlighting the dominant position of students, strengthen the sense of innovation and entrepreneurship education

To increase the richness of the teaching materials, the students should be required to collect information. The teaching of the teachers should not be given priority to the information of knowledge theory. It should guide the students to study and analyze the data, guide the students to put forward their views and new problems, think about the new problems, and improve the students' ability to discover problems, analyze and solve the problems and solve the problems. Creative thinking and creative ability. To guide students to actively participate in the discussion of the practical problems of tourism management, to put forward their views, to find and strengthen their strengths in the communication, to form a strong ability in one aspect, so as to develop and realize the development of entrepreneurship. Using Tourism Internet to make and guide students' practice of tourism and entrepreneurship, and train students' entrepreneurial ability in tourism.

Strengthen school-enterprise cooperation, innovation and entrepreneurship students

Carry out the practice of innovation and entrepreneurship education in tourism management, organize students to visit tourism enterprises, let students directly contact with tourism services and management, observe the innovative and entrepreneurial qualities that tourism workers should possess, and strengthen the training of innovation and entrepreneurship skills in activities. At the same time, the management personnel of the tourism enterprises are invited to the school to carry out the guidance or lectures on innovation and entrepreneurship education, to open symposiums, seminars, etc., so that students' understanding of innovation and entrepreneurship education is more specific and visual, and consciously pay attention to the cultivation of innovation and entrepreneurship awareness and skills. In addition, the use of off-campus internship training bases, arrange student internships, encourage students to actively participate in social production practices, and improve their ability to innovate and create.

\section{Conclusion}

The organic integration of professional education and innovation and entrepreneurship education is the new mission entrusted by the times to higher education. The specialty of Tourism Management in Colleges and universities should be based on the orientation of its own development, take the social demand as the guidance, fully excavate the innovation and entrepreneurship education resources in the specialty, and promote the close docking of the talents training with the economic and social development and the innovation and entrepreneurship needs, and realize the organic 
connection between the tourism human resource market and the innovative and entrepreneurial talents. The major of Tourism Management in Colleges and universities should adjust the talent training plan timely, and construct a curriculum system integrating tourism management education with innovation and entrepreneurship education.

\section{Acknowledgement}

HKJG2018-10,Teaching reform of Hainan tourism route design application course.

\section{References}

[1]Jiang N Y, University N N. On the Construction of Innovation and Entrepreneurship Education System in Engineering Education Talents[J]. Journal of Jinling Institute of Technology, 2015.

[2]Xiao-Hua L I, Zhang L P, Wang X F. A Research on Innovation and Entrepreneurship Education System Construction of Local Colleges and Universities[J]. Journal of Hebei University of Science \& Technology, 2015.

[3]Hong-Tao L I, Ying H, Lai P F. Exploration and Construction of Innovation and Entrepreneurship Training System for Local College Students[J]. Northwest Medical Education, 2013.

[4]Peng J Z, Zhang B H, Zhou Y. Research on the Construction of Innovation and Entrepreneurship Curriculum System in Industry-Based Characteristic Universities_-A Case Study of Energy and Electricity University[J]. China University Students Career Guide, 2017.

[5]Liu D, Chen Y. Research on the Construction of Music Curriculum System Based upon Innovation and Entrepreneurship Education—a Case Study of Shaoguan University[J]. Journal of Shaoguan University, 2013.

[6]Yang B, Jun-Yi G E. On the Construction of Innovation and Entrepreneurship Education System in Open University[J]. Journal of Hunan Radio \& Television University, 2014, 54(60):131-136.

[7]Zhang Q, Li-Qun W U. Construction of the Ecological System of Innovation and Entrepreneurship Education in Higher Education Based on Collaborative Culture[J]. Research on Higher Education of Nationalities, 2015.

[8]Li G, Wang L. Study on the Curriculum System of the Cultivation of Innovation and Entrepreneurial Talents Majoring in Electronic Commerce[C]// International Education, Economics, Social Science, Arts, Sports and Management Engineering Conference. 2016.

[9]Yang Y, Wang F, Qing H E. Research on the Construction of Innovation and Entrepreneurship Education System of Economics and Management Specialty in Independent College_-Take Nanyue College of Hengyang Normal University as an example[J]. Guide of Science \& Education, 2017.

[10]Wang Y. A Study on Construction of Innovation and Entrepreneurship Education Curriculum System of Tourism Management in Universities[C]// International Conference on Education, Management, Computer and Medicine. 2017.

[11]Zhou Y. On the Innovation and Entrepreneurship Education of Undergraduate Tourism Management Specialty in Higher Vocational Education[C]// International Conference on Economics and Management, Education, Humanities and Social Sciences. 2017.

[12]Guo M. Study on the Construction of the Curriculum System of Innovation and Entrepreneurship Education in Independent Colleges[J]. Journal of Guilin Normal College, 2017.

[13]Yang G Z. Study on the Establishment of Innovation and Entrepreneurship Education Curriculum System in Independent Colleges[J]. Education Teaching Forum, 2018.

[14]Zhang W B, Liu M, Tan X B, et al. Research and Practice on the Construction of Multi-information Curriculum System Based on Innovation and Entrepreneurship[J]. Value Engineering, 2018. 